\title{
Apprenticeship and Junior Secondary School Students'Academic Performance in Ado-Odo/Ota Local Government of Ogun State, Nigeria
}

\author{
ABARI, Ayodeji Olasunkanmi (Ph.D) $)^{1 *}$, ADETUNJI, Olayemi Kafayat ${ }^{1}$, ONILUDE, Olusegun \\ Adeniran $^{1}$, ORUNBON, Nurudeen Olalekan ${ }^{1}$ \\ ${ }^{I}$ Department of Educational Management Lagos State University, Lagos, Nigeria
}

*Corresponding Author: ABARI, Ayodeji Olasunkanmi, Department of Educational Management Lagos State University, Lagos, Nigeria

\begin{abstract}
The practice of apprenticeship by secondary school students is observed among some relatively few Nigerians to earn a living either now or later in the future. This looks parallel to the practical solution that is recently being proffered and employed in the name of entrepreneurship studies in higher educational institutions in order to ameliorate the problem of graduate employment. It is in the light of this that this study examined the relationship between apprenticeship and students' academic performance in public junior secondary schools in Ado-Odo/Ota local Government of Ogun State, Nigeria. The study sample consisted of 15 public schools selected from a population of 48 on a stratified random basis. Ten teachers were randomly selected and ten Junior Secondary 2 students were purposively selected from each sample school to participate in the study. The participants responded to separately designed, validated and reliably tested questionnaires ( $r=0.87$ and 0.91 respectively) for teachers and students to collects pertinent data on apprenticeship. The study also gathered data, through Records Observation, on the academic performance of students. The collected data were employed in the test of the research hypotheses. Results of the analyses indicate no significant relationship between apprenticeship and academic performance and, no significant difference in academic performance between students on apprenticeship and students not on apprenticeship, and between male and female students on apprenticeship. The study recommends, among others, more or practical activities than theoretical lessons in Basic Technology and other hands-on subjects such that at the end of the 3-year Junior Secondary School, students could be certified in a trade subject to practice and earn a living from it.
\end{abstract}

Keywords: Apprenticeship; Academic Performance; Junior Secondary Schools; Entrepreneurship.

\section{INTRODUCTION}

All Over the world, education has been seen as an indispensable whole instrument which transforms an individual's values, beliefs and behaviours.

Consequently, it is regarded as an agent for change and a catalyst for modernization in any country of world. Education helps every society to preserve its cultural setting and acquire knowledge and skill so that adaptation to the prevalent environmental condition can be attained. Therefore, education is the process of developing the cognitive, affective and psychomotor domains of individuals and groups in order to equip them with the knowledge and skill necessary to survive and make progress in human society.

Agboola and Olaoye (2008), having recognized the importance of education to the upliftment of individual and societal standards, and to countries, individuals, communities and corporations, acknowledge that there is need to pump money into the upliftment of education for better academic performance. Secondary Education is the Education students received after primary School Education and before the tertiary Educational Stage. Secondary Education is given essentially for the preparation of its beneficiaries for useful living within the society. The broad goals of secondary education as stated in the National Policy on Education (2004) shall be to prepare the individual for:

a. Useful living within the society and Higher Education

b. Higher education 
In specific terms:

a. Provide all Primary School leavers with opportunity for Education of a higher level, irrespective of sex, social status, religious or ethnic background.

b. Offer diversified curriculum to cater for the differences in talents, opportunities and future roles.

c. Inspires students with a desire for self improvement and achievement of excellence.

d. Raise a generation of people who can think rationally for themselves, respect the views and feelings of others, respect the dignity of labour, appreciate_ those values specified under our broad national goals and live as good citizens (National Policy on Education, 2004).

To achieve the stated goals, secondary education shall be of six years duration, given in two stages which are (i) a junior secondary school stage and (ii) a senior secondary school stage; each shall be of three years education. The Ogun State Teaching Service Commission (TSC) stratified Secondary School into two in September 2005. The Junior Secondary and the Senior Secondary headed by two different Administrative Officers. As the focus of this study, the junior Secondary School comprises both pre-vocational and academic performances.

Every student shall offer a minimum of 10 subjects and a maximum of 13 subjects, which include English Language and mathematics, one major Nigeria Language other than that of the Environment, Basic Technology, Cultural and Creative Arts, Physical and Health Education, Home economics, Computer Studies, French Social Studies or Civic Education, basic Science and either Christian Religious Studies or Islamic Religion Studies. The streaming shall be based on the result of tests to determine ability and performance and vocational interests.

Despite all these programmes, at junior Secondary Level, through observations, it has been seen that the rate at which students embark on apprenticeship after school hours is alarming in Ado-Odo/Ota Local Government Area of Ogun State and therefore Academic performance of students seems poor. However, after school hours, apprenticeship here is a method whereby a student after leaving school at closing hours of $2 \mathrm{pm}$ either goes straight to workshop or snappily branched home to drop his or her bag before taking off to the workshop. This system as practiced in the Nigeria society does not give room to the students to revise their school in order to effectively absorb all that has been imparted into them at school nor does it allow them time to rest. The apprenticeship skills being acquired is not in any-way related to their activities at school hence no correlation. Yet, the desire of every teacher/parent is to see students excel in their academic pursuit and not vice versa.

Apprenticeship is a combination of on the job and related classroom/workshop instruction under the supervision of a journey-level craft person or trade professional in which a worker learns the practical and theoretical of highly skilled occupation (Barab and Hayke, 2001). Also it is a system of training a new generation of practitioners of structured competency in a basic set of skills. On other hand, Academic performance is the responsiveness of students according to the set standard. Academic performance is the outcome of education, the extent to which a student, teacher, or institution achieved set out educational goals. Academic performance is commonly assured by examinations or continuous assessment but there is no general agreement on how it is best tested or which aspects are the most important (Pratt, 1998).

Today, apprenticeship situation is in contrary to the olden days situation in which apprentices are unto the fullest custody and care of craft masters.

Nowadays, the Local Apprenticeship system in Nigeria is not Government regulated. It is left entirely under the control of each trade association and master craftman popularly known as 'Oga' in Nigerian parlance to decide on what to teach and what not to teach. Apprenticeship usually starts from age 10 up to 18. Older people are also accommodated (Fafunwa, 1974).

Depending on trade, years of apprenticeship range between 2 to 7 years. Agreement on duration will be made between the apprentice and the master and fee will be paid. At the end of the apprenticeship, a freedom ceremony shall hold where demand for some items by the master shall be made. Also apprentices perform domestic chores for the master aside from learning the job (Brandt and Buckmaster, 1993). Apprentices are not longer bound body and soul to their master's house, nor are they dependent upon a master for handouts, food, a little clothing or a few uncertain Naira. Also, 
apprentices are members of the production force as they train on the job and in the classroom or work place, a regular work a week or half a day or after school and live in their own home rather than that of a master's as it were in the olden days. Their agreement sets out the work processes in which they are to be trained and the training period. At the end of their training period, they receive certificates of completion and competency in the skill acquired regardless of their academic certificates.

Observation of students schooling in Ado-Odo/Ota Local Government of Ogun State has shown that quite a large percentage of the population of junior Secondary School Students engage in apprenticeship after school hours which does not allow such students to do their school assignments, read their books at home and do other academic works. They are learning different skills according to their choices and interest in order to become auto-mechanics, hair-dressers, plumbers, electricians, Computer Operators, Bricklayers, Tailors and so on.

\section{Statement of the Problem}

The rate at which students perform in their continuous assessment, examination, has become a great concern to Teachers, Parents/Guardians, Educationists and Government. Meanwhile, Junior Secondary School Teachers in Ado-Odo/Ota of Ogun State put the blame on the parents who allow their children to learn a trade or two after school hours and not giving them opportunity to study at home.

\section{Purpose OF THE STUdy}

The purpose of the study was to:

1. Examine the relationship that exists between students' apprenticeship and academic performance in the junior Secondary School in Ado-Odo/Ota Local Government of Ogun State.

2. Examine the relationship that exists between students on apprenticeship and student not on apprenticeship and academic performance in the junior Secondary School.

3. Find out the difference between male and female junior Secondary School Students in apprenticeship and academic performance in AdoOdo/Ota Local Government of Ogun State.

\section{RESEARCH QUESTIONS}

This study was geared towards answering the following research questions:

1. What is the relationship that exists between students' apprenticeship and academic performance in the Junior Secondary Schools in Ado Odo/Ota Local Government of Ogun State?

2. What is the difference that exists between students' on apprenticeship and students' not on apprenticeship in their academic performance in the junior Secondary Schools in Ado-Odo/Ota Local Government of Ogun State?

3. Is there any difference between male and female junior secondary school students in apprenticeship and academic performance in Ado-Odo/Ota Local Government of Ogun State?

\section{RESEARCH HYPOTHESES}

The following research hypotheses were formulated to serve as a guide to this study:

$\mathrm{H}_{\mathrm{o} 1}$ : There is no significant relationship between student's apprenticeship and academic performance in junior Secondary Schools in AdoOdo/Ota Local Government of Ogun State.

$\mathrm{H}_{\mathrm{o} 2}$ : There is no significant difference between junior Secondary School students on apprenticeship and students not on apprenticeship in their academic performance in Ado-Odo/Ota Local Government of Ogun State.

$\mathrm{H}_{03}$ : There is no significant difference in apprenticeship and academic performance between male and female junior Secondary Schools Students in Ado-Odo/Ota Local Government of Ogun State

\section{SignifiCANCE OF THE STUdy}

It is hoped that this study research work will help to expose if mainly students apprenticeship is majorly the causes of poor academic performance. 
Also, through this research work, encouraging students achieve academic parents/guardians, teachers while schooling and its effects on academic parents/guardians will work towards not apprenticeship coupled with schooling in order to excellence. Finally, it will orientate both the students, on the disposition of student's apprenticeship performances.

\section{Methodology}

\subsection{Research Design}

The researcher adopted descriptive design and correlation design method. Descriptive design method will be used first to study the current status of the independent and dependent variables for the purpose of clarity, understanding, control and subsequent investigation, while correlation design method was then used to establish the relationship between independent variable 'Apprenticeship' and dependent variable 'student academic performance'.

\subsection{Population of the Study}

The target population for the study comprised all the junior secondary school students and teachers in the 48 secondary schools in Ado- Odo/Ota Local Government of Ogun State. The schools were stratified into the major towns and suburbs that make up Local Government namely Sango, Ijoko/Itoki, Ota, Iju/Onibuku Ota, Ilogbo, Atan and Ado-Odo such that there will be at least one school from the five suburbs and five each from the major towns of Ado-Odo and Ota.

\subsection{Sample and Sampling Technique}

The sampling technique used for the study was the stratified random sampling technique in which is junior secondary schools (based on one-third of number of schools) are selected from the 48 secondary schools in Ado- Odo/Ota Local Government. Ten teachers and ten students were selected from each sample school to constitute the 300 participants in the study.

\subsection{The Research Instruments}

The instruments used for data collection are a questionnaire for the teachers named Teachers Questionnaire on Apprenticeship (TQA) and a questionnaire for students, Students' Questionnaire Apprenticeship (SQA). The teacher's and students' questionnaire are made up of two sections A and B. section A seek respondents' personal data, while section B was designed to obtain participants responses in the structured items on apprenticeship. Also, data on the academic performance of students in English Language, Mathematics, and Basic Science in the Internal Examination for 1st term 2013/2014 academic session were extracted as a measure of students' performance.

\subsection{Method of Data Collection}

The researchers made personal visits to the selected schools to administer the respondents. With the permission of the school principals, questionnaire were administered and completed by both the students and the teachers. The researchers collected the completed questionnaires on the same day to ensure high rate of returns. Also, the academic performance of students was extracted from available records.

\subsection{Method of Data Analysis}

The data collected from the schools through the questionnaire were scored carefully on 4 point Likert - scale 1,2, 3 and 4 in the order of ascending. The average percentage of responses of the teachers on apprenticeship techniques will be determined for each sample school based on hypotheses generated.

Also, the students' academic performance in 1st term result of 2013/2014 was obtained from the principal of the sampled schools and scored on the credit passes in core subjects (English, Mathematics and Basic Science). The average percentage of students' who passed the 3 subjects at credit level was taken as score of Students' Academic Performance (SAP) for each school.

The Statistical Programme for Social Sciences (SPSS) version 17 computer package was used for the computation and analysis of the data. Pearson product- moment correlation co-efficient will be used to establish the relationship between the independent variable and the dependent variable. 


\section{TEST OF HYPOTHESES}

\section{Results}

$\mathbf{H}_{01}$ : There is no significant relationship between students' apprenticeship and academic performance in Junior Secondary Schools in Ado-Odo/Ota Local Government of Ogun State.

Relationship analysis between students' apprenticeship and academic performance.

\section{Descriptive Statistics}

\begin{tabular}{|l|l|l|l|}
\hline & Mean & Std. Deviation & N \\
\hline Student apprenticeship & 37.5000 & 20.20726 & 4 \\
academic performance & 37.5000 & 21.01587 & 4 \\
\hline
\end{tabular}

\section{Correlations}

\begin{tabular}{|l|l|c|}
\hline & $\begin{array}{l}\text { Student } \\
\text { apprenticeship }\end{array}$ & $\begin{array}{l}\text { academic } \\
\text { performance }\end{array}$ \\
\hline Student apprenticeship Pearson Correlation & 1 & -.58 \\
Nig. (2-tailed) & 4 & .411 \\
N & & 4 \\
\hline Academic performance Pearson Correlation & -.589 & 1 \\
Sig. (2-tailed) & .411 & 4 \\
N & 4 & \\
\hline
\end{tabular}

The analysis of data revealed that the correlation is moderate, negative and not significant. $[\mathrm{r}=-.589$, $\mathrm{N}=4 ; \mathrm{P}>.05]$. This indicates that the test hypothesis that there is no significant relationship between students' apprenticeship and academic performance is hereby accepted. By implication, there is no significant correlation between students' apprenticeship and academic performance in junior Secondary School Students in Ado-Odo/Ota Local Government of Ogun State. However, there is a moderate negative relationship (though not significant) showing that there is an inverse relationship between the two variables of interest. That is, as a student is involved in apprenticeship, the academic performance declines and vice versa.

$\mathbf{H}_{02}$ : There is no significant difference between junior Secondary School students on apprenticeship and students not on apprenticeship in their academic performance in Ado-Odo/Ota Local Government o€ Ogun State.

Differences between junior Secondary School Students on apprenticeship and students not on apprenticeship in their academic performance.

\section{Group Statistics}

\begin{tabular}{|l|l|l|l|l|}
\hline Group & $\mathrm{N}$ & Mean & Std. Deviation & Std. Error Mean \\
\hline JSS 1.00 & 4 & 37.5000 & 22.54625 & 11.27312 \\
Students 2.00 & 4 & 37.5000 & 10.40833 & 5.20416 \\
\hline
\end{tabular}

\section{Independent Samples Test}

\begin{tabular}{|c|c|c|c|c|c|c|c|c|c|}
\hline & \multicolumn{2}{|c|}{\begin{tabular}{l}
\multicolumn{2}{l}{ Levene's } \\
Test for \\
Equality of \\
Variance \\
\end{tabular}} & \multirow[b]{3}{*}{$\mathrm{T}$} & \multirow[b]{3}{*}{ df } & \multirow{3}{*}{$\begin{array}{l}\text { Sig } \\
(2- \\
\text { tailed })\end{array}$} & \multirow{3}{*}{$\begin{array}{l}\text { Mean } \\
\text { Difference }\end{array}$} & \multirow{3}{*}{$\begin{array}{l}\text { Std. Error } \\
\text { Difference }\end{array}$} & \multirow{2}{*}{\multicolumn{2}{|c|}{$\begin{array}{l}95 \% \text { Confidence } \\
\text { Interval of the } \\
\text { Difference }\end{array}$}} \\
\hline & \multirow[b]{2}{*}{$\mathrm{F}$} & \multirow[b]{2}{*}{ Sig. } & & & & & & & \\
\hline & & & & & & & & \begin{tabular}{|l|} 
Lover \\
\end{tabular} & Upper \\
\hline $\begin{array}{r}\text { JSS Students Equal } \\
\text { Variance } \\
\text { Assumed } \\
\text { Equal } \\
\text { Variances } \\
\text { Not assumed }\end{array}$ & 1.615 & .251 & $\begin{array}{l}.000 \\
.000\end{array}$ & $\begin{array}{l}6 \\
4.233\end{array}$ & $\begin{array}{l}1.000 \\
1.000\end{array}$ & $\begin{array}{l}.00000 \\
.0000\end{array}$ & $\begin{array}{l}12.41639 \\
12.41639\end{array}$ & $\begin{array}{l}- \\
30.38180 \\
- \\
33.76682\end{array}$ & $\begin{array}{l}30.38180 \\
33.76682\end{array}$ \\
\hline
\end{tabular}


The mean score of the students engaged in apprenticeship is 37.5000 and $\mathrm{SD}=22.54625$ while the mean score of students who are not engaged is 37.5000 and $\mathrm{SD}=10.40833$. [ $\mathrm{t}(6)=.000, \mathrm{P}>.05]$. The analysis shows that the result is not statistically significant. This means, the test hypothesis that states there is no significant differences between junior Secondary School students on apprenticeship and those not :)n apprenticeship in their academic performance is accepted. Therefore, the students on apprenticeship which are represented by group 1 in Table 4.2 above are not different in their academic performance from those that are not engaged in apprenticeship which are represented by group 2 .

$\mathbf{H}_{03}$ : There is no significant difference in apprenticeship and academic performance between male and female junior secondary school students in Ado-Odo/Ota Local Government of Ogun State.

Differences Between Male and Female Students and Academic Performance.

\section{Group Statistics}

\begin{tabular}{|l|l|l|l|l|}
\hline & & & & Std. Error \\
\hline Group & $\mathrm{N}$ & Mean & Std. Deviation & Mean \\
\hline Male- 1.00 & 4 & 37.5000 & 35.23729 & 17.61865 \\
\hline Female 2.00 & 4 & 37.5000 & 42.72002 & 21.36001 \\
\hline
\end{tabular}

Independent Samples Test

\begin{tabular}{|c|c|c|c|c|c|c|c|c|c|}
\hline & \multicolumn{2}{|c|}{$\begin{array}{l}\text { Levene's } \\
\text { Test for } \\
\text { Equality of } \\
\text { Variance }\end{array}$} & & & & & & & \\
\hline & \multirow[b]{2}{*}{$\mathrm{F}$} & \multirow[b]{2}{*}{ Sig. } & \multirow[b]{2}{*}{$\mathrm{T}$} & \multirow[b]{2}{*}{$\mathrm{df}$} & \multirow{2}{*}{$\begin{array}{l}\text { Sig } \\
(2- \\
\text { tailed })\end{array}$} & \multirow{2}{*}{$\begin{array}{l}\text { Mean } \\
\text { Differe } \\
\text { nce }\end{array}$} & \multirow{2}{*}{$\begin{array}{l}\text { Std. Error } \\
\text { Differenc } \\
\text { e }\end{array}$} & \multicolumn{2}{|c|}{$\begin{array}{l}95 \% \text { Confidence } \\
\text { Interval of the } \\
\text { Difference }\end{array}$} \\
\hline & & & & & & & & Lover & Upper \\
\hline $\begin{array}{cc}\text { JSS Students } & \text { Equal } \\
& \text { Variance } \\
& \text { Assumed } \\
\text { Equal } \\
\text { Variances } \\
\text { Not assumed }\end{array}$ & 0.11 & $\begin{array}{l}.92 \\
0\end{array}$ & .000 & $\begin{array}{l}5.79 \\
0\end{array}$ & 1.000 & .00000 & 27.68875 & $\begin{array}{l}- \\
67.75192 \\
- \\
68.35062\end{array}$ & $\begin{array}{l}65.7519 \\
2\end{array}$ \\
\hline
\end{tabular}

The analysis revealed that the mean score of the 2 groups are the same but the standard deviation of the 2nd group [female] was higher than the 1 st group [male]. [ $\mathrm{t}(6)=.000, \mathrm{P}>.05]$. The difference was not statistically significant. This means the test hypothesis that states 'there is no significant difference in apprenticeship and academic performance between male and female is accepted. Therefore, the apprenticeship of both male and female students does not affect their academic performance.

\section{DISCUSSION OF FINDING}

The findings of this Study reveal that there is no significant relationship between students' apprenticeship and academic performance in Junior Secondary schools in Ado-Odo/Ota Local Government of Ogun State. This implies that apprentices will either improve or not improve their academic performance but rather personal effort had to be made of Student reading abilities. It was also found in this study that there is no difference between those students on apprenticeship and students not on apprenticeship in the junior Secondary School of Ado-Odo/Ota Local Government of Ogun State.

The finding of this study indicates that the male and female students needs to improve on their academics as to this has nothing to do with apprenticeship.

\section{CONCLUSION}

Based on the findings of this study, it is noted that students' apprenticeship in junior Secondary Schools in Ado-Odo/Ota Local Government of Ogun State has nothing to do with the students' academic performance. When a student studies well, the end result is good academic performance but if not, the end result is otherwise. 


\section{RECOMMENDATIONS}

The following recommendations are made based on the findings and conclusion of this study.

1. The students should cultivate more study habits on their own.

2. Parents should be advised during P.T.A. meetings to encourage their wards to create more time for their studies after school hours.

3. Take home assignments should be more comprehensive, so that the student time at home will be judiciously used on their studies.

4. Student involvement in apprenticeship will create room for Small and Medium Entrepreneurship (SME) which will curb unemployment

5. Educational planner should incorporate apprenticeship and entrepreneurship studies into school curriculum in order to create self employment and non reliance on white collar jobs.

\section{REFERENCES}

[1] Agboola, T. and Olaoye, 0.0. (2008). Labour supply and manpower development strategies in the Nigerian building industry. A paper presented at the First Department Staff/Students seminar, Department of Urban and Regional Planning.

[2] Barab, S. A. \& Hay, K.E. (2001). Issues related to the science apprenticeship camp. Journal of Researcher Science Teaching.

[3] Brandt, B.L. Farmer, JR. J.A \& Buckmaster, A (1993). Cognitive apprenticeship approach to helping adults Learn. New directions for adult and continuing education.

[4] Fafunwa, A. B. (1974). History of Education in Nigeria. London: Georgia Allen and Union Limited.

[5] Federal Republic of Nigeria, (2004). The national Policy on Education. Lagos Federal Ministry of Education.

[6] Pratt, D.D, (1998). Five perspectives on teaching in Adult and Higher Education. Malabar, Fl: Krieger Publishing Company.

\section{AUTHORS' BIOGRAPHY}

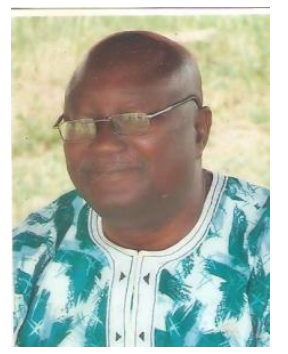

Dr., ABARI Ayodeji Olasunkanmi, holds a Bachelor of Science Degree in Education and Biology (B.Sc Education./Bio.), a Master of Arts degree in Education (M.A. Ed.) with specialization in Educational Administration, a Doctor of Philosophy (Ph.D) Degree also in Education and Educational Administration, all of the Obafemi Awolowo University, Ile-Ife, Osun State, Nigeria. Today, Dr. Abari is an Associate Professor in the department of Educational Management, Faculty of Education, Lagos State University, Lagos, Nigeria with a lot of teaching and administrative experience. He has published several articles in National and International Journals and conferences. He is happily married with children.

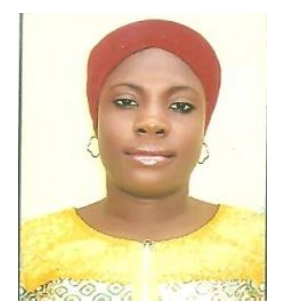

ADETUNJI, Olayemi Kafayat, had her first degree in Tai Solarin University of Education in Affiliation with University of Ibadan and her Master Degree in Educational Management and currently a Doctoral (Ph.D.) student with specialization in Educational Administration, both in Lagos State University, Ojo, Lagos Nigeria. She is presently a teacher in Ogun State Teaching Service Commission. She is happily married with children.

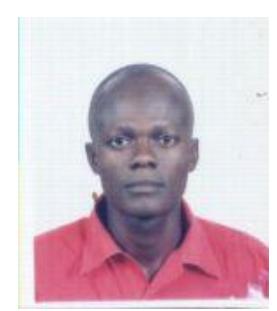

ORUNBON, Nurudeen Olalekan, holds a Nigeria Certificate in Education (NCE) at Adeniran Ogunsanya College of Education, Lagos, Nigeria, a Bachelor of Science Degree in Education and Political Science, a Master Degree in Educational Management and currently a Doctoral (Ph.D) student with specialization in Educational Administration all of Lagos State University, Ojo, Lagos, Nigeria. During his undergraduate he was a University Scholar. He teaches courses at Sandwich undergraduate degree programme in Lagos State University.

$\mathrm{He}$ is open to any form of collaborative research. He is happily married. 


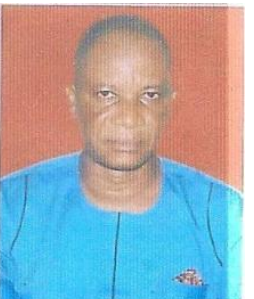

ONILUDE, Olusegun Adeniran, was born in Badagry, Lagos State, and had his first degree at Ogun State University, Ago-Iwoye now Olabisi Onabanjo University. He did his Masters in Public Administration (MPA) and Educational Management both at Lagos State University (LASU). Current he is a doctoral student of Educational planning and policy at Lagos State University, LASU, Ojo. He has vast experience in teaching in Primary, Secondary and Tertiary Institutions. He is happily married with children.

Citation: ABARI, Ayodeji Olasunkanmi, ADETUNJI, Olayemi Kafayat, ONILUDE, Olusegun Adeniran, ORUNBON, Nurudeen Olalekan. "Apprenticeship and Junior Secondary School Students' Academic Performance in Ado-Odo/Ota Local Government of Ogun State, Nigeria." International Journal of Humanities Social Sciences and Education (IJHSSE), vol 5, no. 1, 2018, pp. 135-142. doi: http://dx.doi.org/10.20431/2349-0381.0501021.

Copyright: (ㅇ 2018 Authors. This is an open-access article distributed under the terms of the Creative Commons Attribution License, which permits unrestricted use, distribution, and reproduction in any medium, provided the original author and source are credited. 